Article

\title{
FDI Inflows, Price and Exchange Rate Volatility: New Empirical Evidence from Latin America
}

\author{
Silvia Dal Bianco ${ }^{1, *}$ and Nguyen Cong To Loan ${ }^{2}$ \\ 1 University College London, School of Slavonic and East European Studies, Gower St., Kings Cross, \\ WC1E 6BT London, UK \\ 2 USAID Governance for Inclusive Growth Program, TNR Building, 115 Tran Hung Dao St., Hoan Kiem Dist., \\ 10000 Hanoi, Vietnam; Loan.Nguyen@vietnamgig.com \\ * Correspondence: s.dalbianco@ucl.ac.uk; Tel.: +44-20-7679-8570
}

Academic Editors: Zhibin Lin, Ling Xiao, Nirmala Lee, Chi Keung Lau and Satish Sharma Received: 25 August 2016; Accepted: 17 January 2017; Published: 14 February 2017

\begin{abstract}
This paper investigates the impact of price and real exchange rate volatility on Foreign Direct Investment (FDI) inflows in a panel of 10 Latin American and Caribbean countries, observed between 1990 and 2012. Both price and exchange rate volatility series are estimated through the Generalized Autoregressive Conditional Heteroscedasticity model (GARCH). Our results obtained, employing the Fixed Effects estimator, confirm the theory of hysteresis and option value, in so far as a statistically significant negative effect of exchange rate volatility on FDI is found. Price volatility, instead, turns out to be positive but insignificant. Moreover, we show that human capital and trade openness are key for attracting foreign capital. From the policy perspective, our analysis suggests the importance of stabilization policies as well as the policy of government credibility in promoting trade openness and human capital formation.
\end{abstract}

Keywords: FDI; GARCH; real exchange rate and price volatility; Latin America and the Caribbean

JEL Classification: C33; F21; F23

\section{Introduction}

The Organisation for Economic Co-operation and Development (OECD (2008)) [1] defines a Foreign Direct Investment Enterprise as an incorporated or unincorporated enterprise in which a foreign investor owns 10 per cent or more of the ordinary shares or voting power of an incorporated enterprise or the equivalent of an unincorporated enterprise. Hence, the direct investor is able to influence or participate in the management and he/she possesses a long-lasting interest in the enterprise.

The benefits of Foreign Direct Investment (FDI) for a recipient country are both direct (e.g., capital and employment) and indirect (e.g., knowledge transfer), see Lipsey (2000) [2] and Bruno and Campos (2013) [3] for exhaustive reviews.

In the last two decades, the world economy has witnessed a number of economic crises as well as macroeconomic uncertainty. Hence, price and exchange rate volatility have characterized the globalized economic environment, see Bloom (2009) [4], Arellano et al. (2012) [5], Caggiano et al. (2014) [6], Aastveit et al. (2013) [7], and Mumtaz and Surico (2013) [8], among many others. Despite the impact of price and exchange rate volatility on FDI inflows having been widely investigated, from both the theoretical and the empirical perspective, the evidence on Latin American and Caribbean countries is still scant. This is mainly due to scarcity of available data. The Economic Commission for Latin America and the Caribbean (ECLAC) (2015) [9] explicitly calls for further research on this topic, as it is noticed that the impact of currency fluctuations on FDI is uncertain a priori and it depends on 
a number of factors, such as the type of investment, the origin of the investor, the characteristics of the host economy and the time horizon considered.

The main aim of the present work is the empirical assessment of the impact of price and exchange rate volatility on FDI inflows in Latin America. Hence, our objective is to provide a contribution to ECLAC's research call. This appears of extreme relevance, not only for the historical importance of Latin America in terms of both resource-seeking as well as efficiency-seeking investment (see United Nations Conference on Trade and Development (UNCTAD)—World Investment Report, 1991—for FDI trends since 1984; see Dunning (2000) [10] for definitions) but also for trying to better understand the most recent FDI patterns that have characterised the region. Despite the fact that, in the recent past, the macroeconomic environment has been characterised by severe financial turmoil, ECLAC (2013) [11] underlines that, between 1990 and 2012, FDI inflows to Latin America did not only steadily increase (exception made for 2008) but also their distribution between natural resources, manufacturing and services has not shown signs of dramatic structural change. Thus, our research aims at answering the following question: how macroeconomic uncertainty, as proxied by the real exchange rate and price volatility, has influenced FDI inflows to Latin American and Caribbean countries in the last three decades?

More in detail, our study provides an empirical assessment of the impact of price and exchange rate volatility on FDI inflows in 10 selected Latin American and Caribbean countries, observed between 1990 and 2012. In particular, the countries here considered are Brazil, Chile, Paraguay, Uruguay, Mexico, Costa Rica, Nicaragua, Dominica, Dominican Republic and Trinidad and Tobago.

The choice of the countries is dictated by data availability as well as by the use of volatility modeling through Generalized Autoregressive Conditional Heteroscedasticity (GARCH) techniques (see Paragraph 6 for full details). The time span of the study, instead, has been selected in order to include the effects of the 2007-2008 financial crisis but not the effects of the drop in oil prices. As a matter of fact, the great recession in the selected economies came to an end by 2012 (see for more details Dal Bianco et al. (2016) [12]) while the oil prices began to decrease in the same year. The extension of the sampled period, together with further analysis, is left for future research (see Paragraph 5 for details).

The main contribution of the present work is to provide some novel empirical evidence on the impact of price and real exchange rate volatility on FDI inflows in Latin American countries. In particular, we assess two competing hypotheses, which have been lengthily debated in the literature. The first one, due to the seminal work of Abel (1983) [13] and known as the production flexibility argument, asserts that macroeconomic uncertainty should boost FDI and, hence, we shall expect a positive impact of price and exchange rate volatility. The second theoretical view predicts instead a negative effect of macroeconomic uncertainty on FDI. This is the theory of hysteresis and option value, from Dixit and Pindyck (1994) [14].

In line with the established literature on developing economies, our results provide supportive evidence for the theory of hysteresis and option value. More in detail, employing the Fixed Effect estimator and the GARCH model for retrieving the relevant volatility indicators, we find that exchange rate volatility has a negative impact on FDI inflows in Latin America, while price volatility turns out to be positive but insignificant. Hence, our work also shows the importance of the exchange rate as a nominal anchor in the context of Latin America. Moreover, we show that human capital and trade openness are key for attracting foreign capital.

The rest of the paper is organized as follows. The second section reports the estimable equation and the Table of results. The third discusses the original results obtained in light of the relevant literature; it derives some policy implications and it indicates possible lines of future research. The fourth clarifies the methodological steps taken and it provides details on the variables as well as data sets employed. The fifth concludes. 


\section{Literature Review}

Despite the fact that the impact of fluctuations in macro variables on FDI has received a great deal of attention, the established literature remains inconclusive about the sign and magnitude of the exchange rate and price volatility on foreign capital inflows.

As already mentioned in the Introduction, two main theoretical views have emerged: first, the production flexibility argument and, second, the theory of hysteresis and option value.

According to the first one, if the purpose of foreign investors is not to export abroad or re-export but rather to take advantage of production flexibility, macroeconomic uncertainty should boost FDI flows. According to Abel (1983) [13], output price uncertainty increases investment for risk-neutral competitive firms, which face convex costs of adjustment. The main assumption in the production flexibility argument is that producers have the flexibility to adjust variable factors (i.e., capital costs, labor costs etc.) following the price variability as a result of movements in the exchange rate so that they are encouraged to invest more in the host country as the volatility in the exchange rate of the host country rises. In this case, firms give more weight to production flexibility advantage than to the risk of uncertainty. Cushman (1985) [15] reaches the same conclusion, analyzing the pattern of foreign investment, arguing that in response to appreciation risk, Multinational Enterprises (MNEs) reduce exports to the foreign country but they offset the decrease in export, increasing foreign capital input and production.

In general, a positive correlation between the exchange rate or price volatility implies that firms invest more in a foreign market to diversify production, or to use the market as a shock absorber or to compete with rivals within the same industry.

On the other hand, the theory of hysteresis and option value implies a negative sign of uncertainty impact on FDI due to high sunk cost, which further delays investment. Dixit and Pindyck (1994) [14] show that the intrinsic irreversibility of FDI due to a large sunk cost and tendency to delay due to ownership advantage widens the "Marshallian zone of inaction". Under the assumptions of uncertainty and irreversible investment, the real-option theory emphasizes the option value of the flexibility that a firm has in possibly delaying an investment decision in order to obtain more information about the future. Bernanke (1983) [16] asserts that in the presence of uncertainty regarding the effectiveness of the macroeconomic policies, rational agents will withhold their investment decision (considering that these investments are either completely or partly irreversible) until the uncertainty is removed. If it is assumed that investors are risk averse, as opposed to risk neutral, then the overall effect of uncertainty on investment may be negative, Zeira (1990) [17]. Dixit and Pindyck (1994) [14] indicate that the waiting value increases as the uncertainty rises even for a risk-neutral firm. Hence, uncertainty will deter the FDI decisions by foreign firms.

As for completeness, it must be recalled that a third strand of the literature argues that uncertainty may not be a major concern for foreign investors in cases where other economic factors in the host country, and developing countries in particular, significantly determine the level of investment flow (Dehn, 2000) [18]. These are, for example, geographical location, natural resource abundance and infrastructural development. Hence, an insignificant impact of uncertainty on FDI flows is expected.

Turning to the empirical literature, the majority of the studies analyzing the impact of price and exchange rate volatility in developing countries confirms the theory of hysteresis and option value while supportive evidence of the production flexibility argument is found, instead, for developed economies.

As for laggard countries, Udomkerdmongkol et al. (2009) [19] make use of a panel of 16 emerging countries from Latin America, Asia and Africa, observed from 1990 to 2002, to assess the impact of the exchange rate and exchange rate volatility on US FDI outflows to the sampled countries. Using the Fixed Effects estimator and controlling for GDP per capita, GDP growth rate, portfolio investment, shares of exports, shares of the manufacturing sector as well as telephone main lines, the authors find a negative effect of exchange rate volatility on FDI. Hence, they confirm the theory of hysteresis and option value. Another very interesting study is that of Udoh and Egwaikhide (2008) [20]. In particular, 
its aim is assessing the effect of the exchange rate and price volatility on FDI in Nigeria over the period of 1970 to 2005, where both uncertainty indicators were calculated using the GARCH model. Their results show a negative and statistically significant impact of the exchange rate and price volatility on FDI flows. The results concluded that inflation uncertainty and exchange rate volatility negatively and significantly affected the FDI in Nigeria. Finally, again in line with the option value theory, Del Bo (2009) [21] finds that both exchange rate variability and political risk have a dampening effect on FDI flows in a panel of 53 developed and developing countries, between 1982 and 2005. It is worth remarking that, also in this case, exchange rate volatility has been generated through the GARCH model.

Passing now to the studies on developed economies that found supportive evidence for the production flexibility argument, Goldberg and Kolstad (1995) [22] consider quarterly data on bilateral US FDI outflows to Canada, Japan and UK, between 1978 and 1991, and they proxy exchange rate volatility by quarterly real exchange rate standard deviation. They find evidence that exchange rate uncertainty increases FDI by foreign firms, when such uncertainty is correlated with export demand shocks in the markets that they intended to serve. Chowdhury and Wheeler (2008) [23] examine the impact of uncertainty proxied by exchange rate volatility on FDI inflows in four developed countries, i.e., Japan, Canada, US and UK, by applying the GARCH and Vector Autoregressive (VAR) model approach. The results show that exchange rate volatility has a positive and statistically significant impact on FDI in the majority of the sampled countries (i.e., Canada, Japan and US). Supportive evidence for the production flexibility theory is also found by Osinubi et al. (2009) [24] in their study on Nigeria; Dhakal et al. (2010) [25] and Chaudhary et al. (2012) [26] on Asian and East Asian economies.

Mixed results on the impact of the exchange rate and price volatility is found, instead, by Lemi and Asefa (2001) [27] in their analyses of African countries and Ullah et al. (2012) [28] on Pakistan. In particular, Lemi and Asefa (2001) [27] investigate the role of political and economic uncertainty in affecting US FDI outflows to 29 African countries. They make use of the GARCH model to generate uncertainty indicators. They find that, on aggregate, economic and political uncertainty have a statistically insignificant effect while economic uncertainties are the major impediments for US non-manufacturing investors only when coupled with political instability and debt burden of host countries. Ullah et al. (2012) [28] investigate the relationship of FDI and the exchange rate and exchange rate volatility using time-series data of Pakistan over the period 1980-2010, where volatility has been calculated by the ARCH and GARCH model. Local currency depreciation is found to have a positive impact on FDI inflows, while exchange rate volatility seems to have a negative impact. Price volatility is found to be statistically insignificant.

Finally, it is worth recalling that an insignificant impact of the exchange rate and price volatility has also been found by the established litarature. This is the case of Gorg and Wakelin (2002) [29] and their study of US outward (inward) FDI to (from) 12 developed economies between 1983 and 1995. Other examples are Chaudhary et al. (2012) [26] and Nyarko et al. (2011) [30] and their analyses of Asian economies and Ghana, respectively.

\section{Recent FDI Trends in Latin America and the Caribbean}

Despite uncertainties in the global economy, Latin American and the Caribbean countries have attracted a significant amount of Foreign Direct Investment in recent years. Investing in this region is now a central pillar of many international corporations' economic strategies from North America, Europe, and Asia. Interestingly, Latin American companies have also recently made investments in different economic sectors across the region and become an important source of FDI for several Latin American countries (see Santiso (2008) [31]).

According to the latest report of ECLAC, FDI inflow in the region has grown consecutively over the past decade, with the exception of a single year, 2008, during which foreign investment decreased as a result of the global financial crisis. By the year 2011, foreign investment in the region had not only recovered, but had achieved its maximum historic level, exceeding \$120 Billion USD. 
Table 1 shows the average of global annual FDI inflows and outflows of sampled countries (bold figures) and FDI flows between sampled countries and certain geographical regions during the period 2001-2012 (Million US\$). It can be noticed that Brazil, Mexico and Chile are simultaneously the biggest recipients as well as the biggest investors.

Table 1. Foreign Direct Investment (FDI) inflows to and outflows from selected countries/regions, averages 2001-2012. Data in Millions US\$.

\begin{tabular}{|c|c|c|}
\hline Countries/Regions & Inflows & Outflows \\
\hline Brazil & 32,271 & 5515 \\
\hline Europe & 16,332 & 2798 \\
\hline US & 4014 & - \\
\hline Latin America and the Carribean & 3731 & 4913 \\
\hline Asia & 763 & 13.5 \\
\hline Mexico & 24,235 & 7699 \\
\hline Europe & 9402 & - \\
\hline US & 11,350 & 1200 \\
\hline Latin America and the Carribean & 917 & - \\
\hline Asia & 277 & - \\
\hline Chile & 10,962 & 6979 \\
\hline Europe & 2935 & 933 \\
\hline $\mathrm{US}^{1}$ & 2030 & 318 \\
\hline Latin America and the Carribean & 4408 & 3357 \\
\hline Asia & 132 & 358 \\
\hline Dominican Republic & 1656 & 11 \\
\hline Europe & 386 & - \\
\hline US & 439 & - \\
\hline Latin America and the Carribean & 352 & - \\
\hline Asia & - & - \\
\hline Costa Rica & 1343 & 81 \\
\hline Europe & 91 & - \\
\hline US & 374 & - \\
\hline Latin America and the Carribean & 125 & - \\
\hline Asia & 75 & - \\
\hline Uruguay & 1323 & 9 \\
\hline Europe & 229 & - \\
\hline US & 59 & 39 \\
\hline Latin America and the Carribean & 518 & - \\
\hline Asia & - & - \\
\hline Trinidad and Tobago & 1202 & 361 \\
\hline Europe & 203 & - \\
\hline US & 501 & 22.5 \\
\hline Latin America and the Carribean & - & - \\
\hline Asia & 17 & - \\
\hline Nicaragua & 414 & 8 \\
\hline Europe & - & - \\
\hline US & 6.5 & - \\
\hline Latin America and the Carribean & - & - \\
\hline Asia & - & - \\
\hline Paraguay & 194 & 23 \\
\hline Europe & 28 & - \\
\hline US & 86 & - \\
\hline Latin America and the Carribean & 21.6 & - \\
\hline Asia & - & - \\
\hline Dominica & 41 & 3 \\
\hline Europe & 2 & - \\
\hline US & - & - \\
\hline Latin America and the Carribean & 2.8 & - \\
\hline Asia & - & - \\
\hline
\end{tabular}

Source: Calculations by authors based on United Nations Conference on Trade and Development (UNCTAD) data. 
As for the origin of Foreign Investors, Table 2 provides more details on "Top Investors". In particular, the figures here reported are the proportion of Capital Inflows as a proportion of Total Inflows received by the selected Latin American economy. It could easily be noticed that, in most of the cases, FDI from North America (US and Canada) accounted for a large proportion, followed by FDI from some developed countries in the European region (Netherlands, UK, Spain) as well as from Latin American countries with huge consumption capacity (Brazil, Argentina, Mexico).

Table 2. Top Investors.

\begin{tabular}{|c|c|}
\hline Countries & Average FDI Inflows (\%) \\
\hline \multicolumn{2}{|l|}{ Brazil } \\
\hline Netherlands & 18 \\
\hline Canada & 17 \\
\hline US & 14 \\
\hline \multicolumn{2}{|l|}{ Mexico } \\
\hline US & 48 \\
\hline Netherlands & 14 \\
\hline Spain & 14 \\
\hline \multicolumn{2}{|l|}{ Chile } \\
\hline Spain & 16 \\
\hline Argentina & 16 \\
\hline Brazil & 14 \\
\hline \multicolumn{2}{|l|}{ Dominican Republic } \\
\hline US & 27 \\
\hline Canada & 21 \\
\hline Spain & 12 \\
\hline \multicolumn{2}{|l|}{ Costa Rica } \\
\hline US & 61 \\
\hline Netherlands & 9 \\
\hline Mexico & 8 \\
\hline \multicolumn{2}{|l|}{ Trinidad and Tobago } \\
\hline US & 42 \\
\hline Canada & 33 \\
\hline UK & 14 \\
\hline \multicolumn{2}{|l|}{ Uruguay } \\
\hline Argentina & 27 \\
\hline Portugal & 8 \\
\hline Brazil & 6 \\
\hline \multicolumn{2}{|l|}{ Paraguay } \\
\hline US & 67 \\
\hline Brazil & 15 \\
\hline Spain & 8 \\
\hline \multicolumn{2}{|l|}{ Dominica } \\
\hline Latin America and the Carribean & 7 \\
\hline Asia & 2 \\
\hline
\end{tabular}

Source: Calculations by authors based on UNCTAD data. FDI: Foreign Direct Investment.

At this point, it is important to discuss the main patterns of FDI inflows in Latin American and the Caribbean region, with specific reference to the selected economies for the analysis of this research, i.e., South America (Brazil, Chile, Paraguay, Uruguay), Central America (Mexico, Costa Rica, Nicaragua), Caribbean (Dominica, Dominican Republic, Trinidad and Tobago). As uncertainty affects FDI of different purposes differently, exploring the prevalent types of FDI inwards across the region would be useful not only for better understanding of the uncertainty impact on FDI but also for later recommendations of relevant policies.

From a theoretical perspective, FDI can be classified into four groups: (i) resource-seeking FDI, (ii) market-seeking FDI, (iii) efficiency-seeking FDI, and (iv) strategic asset-seeking FDI (Dunning (2000) [10]; Rugman and Verbeke (2001) [32]). Resource-seeking FDI occurs when firms identify specific 
host country locations as attractive natural resources, i.e., for oil and petroleum, minerals, or particular agricultural products, etc. Market-seeking FDI aims at serving domestic markets. Here, goods are produced in the host country and sold in the local market. As a consequence, this type of FDI is driven by domestic demand indicators such as GDP per capita, GDP growth rate, the proportion of middle-class etc., of the host country. Efficiency-seeking FDI is designed to promote a more efficient division of labor or specialization of the existing portfolio of foreign and domestic assets by foreign firms. For this type of FDI, demand factors in the host country are not of much relevance as goods produced in host countries are often for export purpose. A more pertinent factor for this type of investment is the host country's favorable conditions under which foreign firms can export their products to other countries or their home countries, i.e., trade openness, geographical advantages, its participation in regional and international trade and investment agreements etc. Finally, strategic asset-seeking FDI is designed to create synergies with the existing pool of assets under ownership of foreign firms.

UNCTAD (2012) [33] reports that the sectoral distribution of FDI between 1996 and 2011 does not present dramatic structural changes over the years. Natural resources stand at the bottom (around a steady $13 \%$ of the total), followed by manufacturing (30\%) and services (more than $50 \%$ on average).

In general, the services sector receives the largest share of FDI in almost all economies in the region, but the relative importance of natural resources and manufacturing depends on local conditions. Since the 1990s, efficiency-seeking FDI in the manufacturing sector has been more significant in Mexico and some of the countries in Central America and the Caribbean, which produce goods for export mainly to the United States. On the other hand, natural resource-seeking FDI has been concentrated in South American countries and some Caribbean countries. Brazil, in particular, has shown a more diversified pattern, as a large and relatively closed economy with a significant manufacturing sector producing for the domestic market. This overall pattern has not changed substantially over the years.

There are various rationales underlying these trends. First, export-oriented manufacturing is concentrated in Mexico and a few other Central American countries (Nicaragua) and Caribbean countries (Dominican Republic). Investors targeting the United States and Canada market (i.e., investors in electronics, automotive or aerospace sectors) can use these countries as low-cost export platforms to tap into opportunities in the said markets by taking advantage of the commercial integration and linkages that this sub-region has with these markets. Notably, Mexico did particularly well in attracting investment in export-oriented manufacturing, thanks to the country's commercial integration with the United States and Canada through the North American Free Trade Agreement (NAFTA). Mexico has maintained its position as the largest recipient of this type of FDI, with the expanding automotive manufacturing sector nationwide. However, the dependence on targeted markets for exports means that FDI inflows in Mexico and similar countries in the region are more vulnerable to uncertainty and external shocks that these markets may bring.

FDI inflow in South America was a mix of raw-material-seeking and market-seeking activities. The raw-material-seeking pattern is driven by high commodity prices and the endowment of natural resources of this sub-region, leading to its increasing dependence on exporting natural resources such as petroleum, gas, coal etc. FDI seeking natural resources is spurred by public policies that are favorable to foreign investment in industries relating to petroleum and mining, and to the discoveries of new resource deposits in countries such as Chile (copper mining, solar energy, hydrocarbons), Brazil and Paraguay (oil and gas extraction), and Uruguay (wind and solar energy). According to the regional FDI report by ECLAC, in 2012, around 43\% of the FDI in this sub-region is focused on natural resources, which reflects once more the raw-material orientation of South America. Market-seeking FDI into South America is attracted by the rising local demand triggered by higher employment, economic growth and in general, due to the expansion of the middle class, particularly in such countries as Brazil and Chile.

The bulk of FDI flows to the Caribbean countries have been resource- and efficiency-seeking FDI (see ECLAC (2013) [11]). The small size of many Caribbean countries may have precluded 
substantial market-seeking FDI flows. Generally, the most important factor for export-oriented FDI in this sub-region is resource endowment. It is therefore not surprising that the major recipients of FDI in the Caribbean have been the resource-rich countries such as Trinidad and Tobago with remarkable growth in foreign investment in the natural gas and petroleum sector. Dominican Republic has seen substantial FDI inflows into the manufacturing sector, especially textile and apparel activities in the export processing zones. Although FDI inflows into the Caribbean may appear small in absolute terms, they are nonetheless substantial when viewed in relation to the size of these economies.

\section{Results}

\subsection{Estimable Equation}

Drawing from the works of Lemi and Asefa (2001) [27], Ajuwon (2013) [34], Yousaf et al. (2013) [35] and Mahmood et al. (2011) [36], our estimable equation is formally written as:

$$
F D I_{i t}=\beta_{0}+\beta_{1} \pi_{i t}+\beta_{2} R E R_{i t}+\beta_{3} I N S T_{i t}+\beta_{4} G D P P C_{i t}+\beta_{5} T O_{i t}+\beta_{6} H C_{i t}+\beta_{7} I N F R A_{i t}+\varepsilon_{i t}
$$

The subscripts $i$ and $t$ indicate, respectively, country and year. FDI, measured as a percentage of GDP, represents the dependent variable. $\pi$ and RER are price and real exchange rate volatility, both variables are expressed in logarithms; INST represents a proxy for country-specific institutional quality (i.e., political freedom) and it is measured on 1-to-7 scale; GDPPC stands for per capita Gross Domestic Product; TO, HC and INFRA indicate, respectively, trade openness (in \% of GDP), human capital (i.e., literacy rate) and infrastructural development (i.e., number of telephone lines). As is customary, $\varepsilon_{i t}$ represents an idiosyncratic error term.

\subsection{Descriptive Statistics}

Table 3 reports relevant descriptive statistics on the explanatory variables employed by the present analysis, grouped by country. This choice has been taken in order to highlight the within as well as cross-country variation of our independent variables. This, in turn, is an important prerequisite for the efficiency of our estimates. For example, it can be noticed that the sample comprises countries, such as Brazil, that have had chronically high inflation as well as more stable economies, such as Chile and Mexico. Further, smaller Caribbean economies have been characterized by a depreciated real exchange rate (e.g., Costa Rica, Nicaragua and Trinidad and Tobago) while bigger ones (i.e., Mexico and Brazil) experienced an appreciated exchange rate. As for the other variables, the table confirms well-acknowledged stylized facts. Latin American countries are typically middle-income but exhibit a huge degree of income inequality; they are quite open in terms of trade (exception made for the protectionist Brazil); smaller economies' institutional quality has hugely improved in the last 20 years while especially bigger economies are still lacking in infrastructural terms. Finally, as for human capital, huge progress has been made, with the exception of Nicaragua, which has experienced long civil unrest, and Brazil whose territory comprises very remote areas, often populated by indigenous communities that often reject formal federal government education. 
Table 3. Descriptive statistics.

\begin{tabular}{|c|c|c|c|c|c|c|c|c|}
\hline \multirow{2}{*}{ Country } & \multicolumn{4}{|c|}{ Inflation } & \multicolumn{4}{|c|}{ Real Exchange Rate } \\
\hline & Mean & Std Dev & Max & Min & Mean & Std Dev & $\operatorname{Max}$ & Min \\
\hline Brazil & 408.89 & 810.98 & 2735.49 & 4.24 & 116.02 & 22.63 & 157.86 & 81.76 \\
\hline Chile & 8.05 & 6.08 & 22.46 & 0.47 & 94.13 & 7.73 & 107.86 & 80.95 \\
\hline Costa Rica & 12.44 & 5.40 & 26.15 & 4.09 & 87.99 & 6.79 & 107.68 & 78.22 \\
\hline Dominica & 3.49 & 6.10 & 28.38 & -3.46 & 109.26 & 8.70 & 122.96 & 94.68 \\
\hline Dominican Republic & 15.35 & 22.78 & 102.75 & 2.69 & 93.14 & 8.86 & 103.91 & 72.12 \\
\hline Mexico & 13.39 & 10.14 & 34.08 & 3.21 & 101.68 & 11.21 & 120.12 & 73.72 \\
\hline Nicaragua & 608.12 & 1601.19 & 5018.11 & 3.25 & 100.61 & 21.84 & 127.84 & 18.71 \\
\hline Paraguay & 12.41 & 8.72 & 38.45 & 2.04 & 90.77 & 11.09 & 113.38 & 71.61 \\
\hline Trinidad and Tobago & 6.03 & 10.03 & 23.79 & -27.63 & 79.13 & 11.11 & 107.05 & 66.10 \\
\hline \multirow[t]{3}{*}{ Uruguay } & 26.70 & 30.85 & 106.84 & 0.68 & 81.13 & 15.24 & 109.57 & 52.36 \\
\hline & \multicolumn{4}{|c|}{ GDP per capita } & \multicolumn{4}{|c|}{ Trade Openness } \\
\hline & Mean & Std Dev & Max & Min & Mean & Std Dev & Max & Min \\
\hline Brazil & 5280.88 & 2997.00 & 12576.20 & 2526.34 & 22.41 & 4.41 & 28.49 & 14.12 \\
\hline Chile & 6646.53 & 3800.79 & 15245.47 & 2186.65 & 62.01 & 9.47 & 81.62 & 48.73 \\
\hline Costa Rica & 4544.88 & 1979.50 & 9442.66 & 2269.52 & 77.93 & 12.01 & 98.79 & 61.74 \\
\hline Dominica & 4467.11 & 1566.40 & 6913.06 & 2152.86 & 92.49 & 7.97 & 105.74 & 80.92 \\
\hline Dominican Republic & 2947.16 & 1413.98 & 5733.45 & 941.90 & 70.36 & 12.65 & 88.73 & 41.15 \\
\hline Mexico & 6380.82 & 2239.03 & 9817.84 & 2644.20 & 53.78 & 10.39 & 66.77 & 31.40 \\
\hline Nicaragua & 994.75 & 433.57 & 1776.61 & 243.96 & 79.07 & 21.22 & 108.71 & 37.02 \\
\hline Paraguay & 1930.51 & 758.98 & 3814.21 & 1111.30 & 99.79 & 10.54 & 124.01 & 82.82 \\
\hline Trinidad and Tobago & 9043.31 & 5644.62 & 21395.28 & 3562.09 & 100.27 & 20.85 & 163.28 & 68.05 \\
\hline \multirow[t]{3}{*}{ Uruguay } & 6650.09 & 3173.96 & 14727.73 & 2731.95 & 45.21 & 11.18 & 64.89 & 31.44 \\
\hline & \multicolumn{4}{|c|}{ Infrastructure } & \multicolumn{4}{|c|}{ Institutions } \\
\hline & Mean & Std Dev & Max & Min & Mean & Std Dev & $\operatorname{Max}$ & Min \\
\hline Brazil & 15.41 & 6.67 & 22.30 & 5.98 & 2.25 & 0.44 & 3 & 2 \\
\hline Chile & 16.90 & 5.52 & 22.17 & 4.98 & 1.58 & 0.58 & 3 & 1 \\
\hline Costa Rica & 21.04 & 8.27 & 32.59 & 9.06 & 1.00 & 0.00 & 1 & 1 \\
\hline Dominica & 25.08 & 5.36 & 33.96 & 14.04 & 1.21 & 0.41 & 2 & 1 \\
\hline Dominican Republic & 8.68 & 2.01 & 10.99 & 4.00 & 2.33 & 0.64 & 4 & 2 \\
\hline Mexico & 12.52 & 4.28 & 17.82 & 5.75 & 2.88 & 0.85 & 4 & 2 \\
\hline Nicaragua & 3.10 & 1.31 & 4.99 & 1.12 & 3.42 & 0.72 & 5 & 2 \\
\hline Paraguay & 4.63 & 1.26 & 6.44 & 2.50 & 3.42 & 0.50 & 4 & 3 \\
\hline Trinidad and Tobago & 20.55 & 4.25 & 24.98 & 13.04 & 1.79 & 0.78 & 3 & 1 \\
\hline \multirow[t]{3}{*}{ Uruguay } & 24.23 & 6.14 & 30.25 & 12.17 & 1.13 & 0.34 & 2 & 1 \\
\hline & \multicolumn{4}{|c|}{ Human Capital } & & & & \\
\hline & Mean & Std Dev & Max & Min & & & & \\
\hline Brazil & 87.58 & 2.68 & 91.48 & 83.21 & & & & \\
\hline Chile & 96.47 & 1.74 & 99.25 & 93.69 & & & & \\
\hline Costa Rica & 95.21 & 1.50 & 97.64 & 92.79 & & & & \\
\hline Dominica & 96.65 & 1.47 & 99.03 & 94.28 & & & & \\
\hline Dominican Republic & 86.88 & 2.29 & 90.86 & 83.20 & & & & \\
\hline Mexico & 90.86 & 2.07 & 94.23 & 87.55 & & & & \\
\hline Nicaragua & 76.84 & 2.15 & 80.32 & 73.36 & & & & \\
\hline Paraguay & 92.66 & 1.91 & 98.86 & 90.17 & & & & \\
\hline Trinidad and Tobago & 98.01 & 0.58 & 98.86 & 97.06 & & & & \\
\hline Uruguay & 97.40 & 0.68 & 98.40 & 96.29 & & & & \\
\hline
\end{tabular}

Source: Calculations by authors. std dev: standard deviation; max: maximum; min: minimum.

\subsection{Empirical Results}

Table 4 reports the main results of the present analysis. 
Table 4. Estimation results.

\begin{tabular}{cccc}
\hline Dependent Variable: FDI & & & \\
\hline Independent Variable & FE & RE & Pooled-OLS \\
\hline C & $-59.65^{* * * *}$ & $-67.64^{* * *}$ & $12.83^{* * *}$ \\
$\pi$ & $(0.00)$ & $(0.00)$ & $(0.01)$ \\
RER & 0.005 & 0.02 & $0.15^{* * *}$ \\
& $(0.82)$ & $(0.32)$ & $(0.00)$ \\
INST & $-35.31^{* * *}$ & $-35.38^{* * *}$ & $-81.39^{* * *}$ \\
& $(0.00)$ & $(0.00)$ & $(0.00)$ \\
GDPPC & -0.01 & -0.03 & 0.99 \\
TO & $(0.80)$ & $(0.39)$ & $(0.97)$ \\
& -0.05 & 0.05 & $0.3^{* * *}$ \\
HC & $(0.60)$ & $(0.52)$ & $(0.006)$ \\
& $0.22^{*}$ & $0.17^{* *}$ & $0.066^{* * *}$ \\
INFRA & $(0.05)$ & $(0.02)$ & $(0.00)$ \\
& $14.02^{* * *}$ & $15.44^{* * *}$ & $-2.91^{* * *}$ \\
Country dummies & $(0.00)$ & $(0.00)$ & $(0.00)$ \\
Time dummies & 0.22 & 0.12 & $0.47^{* * *}$ \\
F-Stat & $(0.18)$ & $(0.27)$ & $(0.00)$ \\
& Yes & No & No \\
$R^{2}$ & Yes & No & No \\
Adjusted $R^{2}$ & 20.6 & & \\
S.E. of regression & $(0.00)$ & & 0.59 \\
Hausman test, Chi ${ }^{2}: 21.9(0.00)$ & 0.9 & 0.66 & 0.58 \\
\hline & 0.88 & 0.65 & 0.59 \\
\hline
\end{tabular}

Notes: $p$-values in parenthesis; *** stand for $1 \%$ significance; ${ }^{* *}$ for $5 \%$ and ${ }^{*}$ for $10 \%$.

Column 1 in Table 4 reports our preferred estimates, obtained by employing the Fixed Effects estimator with country and year dummies. Our results show that real exchange volatility has a negative and statistically significant negative impact on FDI in Latin American countries. In particular, a percentage change in real exchange rate volatility decreases FDI inflows (as \% of GDP) by more than 35 percentage points. This negative effect on FDI can be due to under-developed exchange rate forward markets, which turn out to be deficient or unable to cover the exchange rate risk related to MNEs' entry in Latin American markets.

Price volatility, instead, seems to exert a positive effect but it turns out to be statistically insignificant. Among the other FDI determinants, human capital is the most important as it is found that a $1 \%$ increase in the literacy rate makes FDI inflows increase by 14 percentage points. Trade Openness has a positive but smaller impact on FDI while domestic market size, institutional quality and infrastructural development are found to be statistically insignificant.

\section{Discussion}

Our results show that the impact of exchange rate volatility is consistent with the hysteresis and real option theory (see Dixit and Pindyck (1994) [14]). Currency volatility delays the entry of multinational firms because volatility increases the option value associated with waiting before incurring the sunk costs necessary to produce in a foreign country.

This finding is also consistent with the nature and characteristics of FDI pattern in selected economies. ECLAC (2013) [11] reports that MNEs investing in the region are either seeking natural resources or export opportunities, or both, rather than new markets in the host countries. For example, $82 \%$ of manufactured units in Mexico are exported, with only the remaining $18 \%$ placed on the domestic market. Similarly, FDI in export-oriented manufacturing is also highly concentrated in other sampled countries (i.e., Nicaragua in garment and apparel manufacturing; Paraguay in cement and 
cable-manufacturing; Costa Rica in the microprocessor industry and Brazil in the automotive, steel and computer industries).

Hence, as FDI in the sampled countries tends to be vertical (i.e., intended for export) rather than horizontal (i.e., aimed at the market of host countries), exchange rate volatility raises demand uncertainty for the export-oriented firms and may decrease the profitability of FDI. Based on this observation, it can be argued that stability in exchange rates promotes FDI inflows in the region.

Turning to inflation rate volatility, it must be noticed that it does not show the expected sign, despite being statistically insignificant. As for the positive effect of price volatility, Hartman (1972) [37] and Abel (1983) [13] suggest that higher price-uncertainty raises the expected profitability of capital, increases the desired capital stock and ultimately increases the level of investment. This argument is based on the assumption of risk neutral investors, which has been put under serious scrutiny by a number of works; see, for example, Sheifler and Vishny (1997) [38]. Another explanation can be related to the fact that, in the presence of increasing inflation, efficiency-seeking/export-oriented MNEs may find it convenient not to procrastinate regarding investment decisions and, hence, invest more. However, the statistical insignificance of domestic price volatility suggests that FDI is less elastic to domestic price fluctuations than to exchange rate volatility.

Passing to human capital, our results are in line with the results of established literature; see, for example, Alfaro et al. (2010) [39]; Alfaro and Charlton (2013) [40]; Bruno and Campos (2013) [3]. Human capital in host countries is an important factor for attracting FDI, as the more educated the labour force, the faster the technological transfer and the lower the transaction costs, such as the costs of training.

As for trade openness, our findings are consistent with those of Amal et al. (2010) [41] and their study on FDI determinants in eight Latin American economies, examined between 1996 and 2008; as well as with the findings of Wang and Swain (1995) [42] obtained for a broader sample of developing countries. The general point is that export-oriented MNEs may prefer to locate in more open economies, in order to minimise the transaction costs associated with exporting. Hence, Trade Openness triggers FDI inflows as the two strategies can be seen as complementary, see for example Ramirez (2014) [43] for a complete review in the context of Latin America.

Turning to market size, proxied by GDP per capita, Table 4 reports a negative although statistically insignificant impact on FDI to Latin America. The negative sign implies that larger market size can hinder the flow of foreign capital. For example, Abekah (1998) [44] argues that, as host economies' GDP grows, capital requirements are increasingly met domestically. Hence, FDI inflows descrease. Moreover, according to ECLAC (2013) [11], the majority of FDI in the region is export-oriented. Hence, the relative size of the domestic market might be less relevant than in the case of market-seeking investment. Finally, the insignificance of the estimated coefficient can be due to the fact that some of the sampled countries are quite small, in terms of population and, hence, domestic market size might not be not such a relevant determinant of FDI.

Concluding the discussion of our results with the effect of institutional quality and infrastructural development, Table 4 shows that both variables turn out to be statistically insignificant. Despite the great attention that political stability has received for explaining FDI flows (see for Latin America, Amal et al. (2010) [41]), the negative and statistically insignificant coefficient is not highly surprising in the present case. This is due to the very low variability of the political freedom indicator here employed. Similar reasoning applies to the infrastructural development proxy. Despite these limitations, the chosen series have the great advantage of being available for all countries in the sampled period.

To summarise, in line with the established literature on developing countries, our study provides strong evidence of a negative impact of exchange rate volatility on FDI inflows in Latin America. Moreover, it shows that price volatility has no statistically significant effects. Finally human capital and trade openness are found to be key factors for attracting foreign capital. 
These findings do not only enrich the literature on the relationship of uncertainty and FDI, by providing new evidence on Latin America but they also bring important policy implications. First, in order to attract FDI in the region, policymakers should promote macroeconomic policies aimed at minimising exchange rate volatility, via the improvement of domestic fundamentals.

Another main finding of this research is that trade openness and an educated labour force in host countries attract FDI. Accordingly, it is recommended that potential host countries maintain an FDI friendly environment by promoting an open trade regime and prioritizing human capital formation. It is important to stress that the full benefits of such policies can be realized only if investors perceive government's efforts as credible and not subject to reversal. As a consequence, governments of host countries should develop mechanisms to enhance the governance credibility and stability.

To conclude our discussion, it is worth noting that our study opens a twofold immediate line for future research. First, it would be important to distinguish among different types of FDI (i.e., vertical, horizontal, market seeking, etc.) as well as to take into account industries' specifities. This calls for the use of more disaggregated data. Second, it would be important to control for external shocks, such as the recent global financial crisis, that have hit developing countries and the ones in the sample after 2012. This means that a full set of tests for structural breaks needs to be carried out and that the dataset must be enlarged in its time dimension.

\section{Materials and Methods}

The present empirical analysis is based on a panel data set of ten FDI recipient countries from Latin America and the Caribbean region, observed between 1990 and 2012. In particular, the sampled economies are Brazil, Chile, Paraguay, Uruguay, Mexico, Costa Rica, Nicaragua, Dominica, Dominican Republic as well as Trinidad and Tobago.

On the one hand, the choice of countries is motivated by data availability and, on the other, by the modeling of the exchange rate and price volatility through GARCH techniques. For example, there is no available real exchange rate time series for Peru. Hence, such a country has been excluded from the analysis. Further, relying on the statistical significance of the GARCH coefficient, we found that such a model can be applied to the selected countries only (See Table 5 for details). Thus, despite the initial sample of countries comprised, from all Latin American and Caribbean economies with relevant time series, the final sample dimension has been reduced to just ten.

Annual data on FDI inflows (in current \$US) and trade openness (measured as the sum of Exports and Imports as \% of GDP) are taken from UNCTAD. Those of the real effective exchange rate index $(2010=100)$, inflation (i.e., GDP deflator), Gross Domestic Product per capita (in current \$US), literacy rate-adult total (\% of people aged 15 years and above), telephone lines per 1000 inhabitants are taken from World Bank's World Development Indicators. Political freedom is taken from Freedom House. It is worth noting that our preference for the aforementioned institutional proxy is motivated by the recent findings of the political science literature, see for example Baccini and Urpelainen (2014) [45] and Buthe and Milner (2008) [46]. In particular, it has been shown that there is a nexus between domestic and international politics for attracting FDI and that the higher the commitment and credibility of domestic policy choices, the higher the FDI. Hence, as our aim is capturing the effect of the institutions that are prominent for FDI attraction, we relied on the Freedom House index, which proxies governments' commitment to democratic values and civil liberties thus providing a measure of government credibility.

Three methodological steps are taken here. First, the Augmented Dickey-Fuller (ADF) Fisher panel unit root test is employed to examine the stationarity of the series. Second, a GARCH $(1,1)$ model is used to generate price and real exchange rate volatility series. Finally, different panel data estimators are employed to assess the impact of volatility on FDI inflows.

Beginning with the ADF-Fisher panel unit root test, testing for data stationarity is a mandatory step (see for full details Engle and Granger (1987) [47], and Granger and Newbold (1974) [48]). The rationale for conducting a panel unit root test instead of an individual unit root test for a single 
series is based on its overwhelming advantages, i.e., more powerful as the information in the time series is enhanced by that contained in the cross-section data; panel unit root tests lead to statistics with a normal distribution in the limit in contrast to individual unit root tests with non-standard limiting distributions (see Baltagi (2001) [49]). Since the power of unit root tests depends on the total variation in the data used (both in the number of observations and their variation), panel unit root tests are more powerful than standard time-series unit root tests because the variation across countries adds a great deal of information to the variation across time, resulting in potentially more precise parameter estimates (see Taylor and Sarno (1998) [50]). Among the available panel unit root tests, the ADF-Fisher test proposed by Maddala and Wu (1999) [51] and Choi (2001) [52] is chosen because, on the one hand, it does not require a balanced panel and, on the other, it can use different lag lengths in the individual ADF regressions.

Table 5 shows the results of the ADF-Fisher panel unit root test. As $\operatorname{Pr}$ [ADF-Fisher Chi-square] $=0.0000<0.01$, the null hypothesis of unit root cannot be rejected at the $1 \%$ level of significance, verifying that all the variables are non-stationary in their level form. Appropriate differencing is made in order to obtain stationary series accordingly based on the automatic lag length selection result.

Table 5. ADF-Fisher panel unit root test.

\begin{tabular}{llc}
\hline Null Hypothesis: Unit Root (Individual Unit Root Process) \\
\hline Series: Group10 & & \\
\hline Sample: $1990-2012$ & & \\
Exogenous variables: Individual effects & \\
Automatic selection of maximum lags & \\
Automatic lag length selection based on SIC: 0 to 4 & \\
Total number of observations: 1717 & & \\
Cross-sections included: 80 & Statistic & Prob. ${ }^{* *}$ \\
Method & 730.197 & 0.0000 \\
ADF-Fisher Chi-square & -6.23911 & 0.0000 \\
\hline
\end{tabular}

Source: Calculations by authors. ${ }^{* *}$ Probabilities for Fisher tests are computed using an asymptotic Chi-square distribution. All other tests assume asymptotic normality. SIC: Schwartz Information Criterion.

Turning now to the GARCH model for modeling volatility (Engle (2001) [53]; Bollerslev (1986) [54]), such a method is based on the assumption that the variance of the error terms of a variable is not equal over time. In particular, it is assumed that the variance is larger in some periods than others and that periods of higher variance are clustered together. The GARCH model is useful in that it uses the heteroscedasticity present in the variables of interest and models it. Such a methodology has been widely used for measuring both the exchange rate (Mahmood et al. (2011) [36]; Chowdhury and Wheeler (2008) [23]) and price volatility (Lemi and Asefa (2001) [27]; Ullah et al. (2012) [28]. Following the methodology described in Engle (2001) [53], we found that both RER and inflation's true variance process can be specified by a GARCH model $(1,1)$. This means that the next period's conditional variance is a weighted combination of the unconditional variance of the variable of interest, last period's squared residuals and last period's conditional variance, where the weights sum to one. Most empirical work finds that the GARCH model $(1,1)$ adequately represents the conditional variance (Bollerslev et al. (1992) [54]), which is expressed in the following Equation (2):

$$
\begin{gathered}
y_{t}=x_{t} \beta+\epsilon_{t} \\
\operatorname{VAR}\left(\epsilon_{t}\right)=\sigma_{t}^{2}=\omega_{0}+\omega_{1} \epsilon_{t-1}^{2}+\omega_{2} \sigma_{t-1}^{2}
\end{gathered}
$$

where: $\omega_{0}>0$ and $\omega_{1}, \omega_{2} \geq 0$; and $x_{t}$ are the variables determining the underlying data generating process with their coefficients $\beta, \epsilon_{t}$ is the error term, $\omega_{0}$ is the constant term, $\omega_{1}$ is the parameter 
coefficient of the autoregressive lag, $\epsilon_{t-1}^{2}$ (ARCH term), $\omega_{2}$ is the parameter coefficient of the moving average lag, $\sigma_{t-1}^{2}$ (GARCH term).

Table 6 reports GARCH $(1,1)$ Estimation Results. The presence of GARCH enables the generation of conditional variance series as the volatility proxy for the exchange rate and inflation rate of the sampled countries.

Table 6. GARCH $(1,1)$ Estimation Results.

\begin{tabular}{|c|c|c|c|c|}
\hline \multirow{2}{*}{ Country } & \multicolumn{2}{|c|}{ Exchange Rate } & \multicolumn{2}{|c|}{ Inflation Rate } \\
\hline & $\operatorname{RESID}(-1)^{2}$ & GARCH $(-1)$ & $\operatorname{RESID}(-1)^{2}$ & GARCH $(-1)$ \\
\hline Brazil & $\begin{array}{c}-0.242809 * * \\
(0.03)\end{array}$ & $\begin{array}{c}1.224323^{* * * *} \\
(0.00)\end{array}$ & $\begin{array}{c}0.252086^{* *} \\
(0.05)\end{array}$ & $\begin{array}{c}1.069232^{* * *} \\
(0.00)\end{array}$ \\
\hline Chile & $\begin{array}{c}-0.099337^{* * *} \\
(0.00)\end{array}$ & $\begin{array}{c}1.207099^{* *} \\
(0.06)\end{array}$ & $\begin{array}{c}-0.163243 * \\
(0.09)\end{array}$ & $\begin{array}{c}1.265033^{* * *} \\
(0.00)\end{array}$ \\
\hline Costa Rica & $\begin{array}{c}-0.185781^{* * *} \\
(0.00)\end{array}$ & $\begin{array}{c}0.802193^{* * *} \\
(0.00)\end{array}$ & $\begin{array}{c}-0.296769 * * * \\
(0.00)\end{array}$ & $\begin{array}{c}1.165327^{* * * *} \\
(0.00)\end{array}$ \\
\hline Dominica & $\begin{array}{c}-0.307346^{* * *} \\
(0.00)\end{array}$ & $\begin{array}{c}1.148021^{* * * *} \\
(0.00)\end{array}$ & $\begin{array}{c}-0.080929 * \\
(0.08)\end{array}$ & $\begin{array}{c}0.575129 \text { **** } \\
(0.00)\end{array}$ \\
\hline Dominican Republic & $\begin{array}{c}-0.127834^{* *} \\
(0.02)\end{array}$ & $\begin{array}{c}0.9474522^{* * *} \\
(0.00)\end{array}$ & $\begin{array}{l}0.517462 * \\
(0.02)\end{array}$ & $\begin{array}{c}1.206939 * * * \\
(0.00)\end{array}$ \\
\hline Mexico & $\begin{array}{c}-0.183920 * * * \\
(0.00)\end{array}$ & $\begin{array}{c}1.216995^{* * *} \\
(0.00)\end{array}$ & $\begin{array}{c}0.614113^{* * *} \\
(0.00)\end{array}$ & $\begin{array}{c}1.233328^{* * * *} \\
(0.00)\end{array}$ \\
\hline Nicaragua & $\begin{array}{c}-0.292102^{* *} \\
(0.05)\end{array}$ & $\begin{array}{c}1.214024^{* * *} \\
(0.00)\end{array}$ & $\begin{array}{c}-0.203875^{* *} \\
(0.06)\end{array}$ & $\begin{array}{c}1.025094^{* * *} \\
(0.00)\end{array}$ \\
\hline Paraguay & $\begin{array}{c}-0.279407 * \\
(0.07)\end{array}$ & $\begin{array}{c}1.352150 \text { ** } \\
(0.04)\end{array}$ & $\begin{array}{c}-0.197464^{* * *} \\
(0.00)\end{array}$ & $\begin{array}{c}0.922821^{* *} \\
0.04)\end{array}$ \\
\hline Trinidad \& Tobago & $\begin{array}{c}-0.218511^{* *} \\
(0.05)\end{array}$ & $\begin{array}{c}1.205980^{* * *} \\
(0.00)\end{array}$ & $\begin{array}{c}0.459849 * \\
(0.08)\end{array}$ & $\begin{array}{c}0.790073^{* *} \\
(0.04)\end{array}$ \\
\hline Uruguay & $\begin{array}{c}-0.183840 \text { * } \\
(0.09)\end{array}$ & $\begin{array}{c}1.136724^{* * * *} \\
(0.00)\end{array}$ & $\begin{array}{c}-0.185693 * * \\
(0.03)\end{array}$ & $\begin{array}{c}1.203486^{* * *} \\
(0.00)\end{array}$ \\
\hline
\end{tabular}

Notes: $p$-values in parenthesis; ${ }^{* * *}$ stand for $1 \%$ significance; ${ }^{* *}$ for $5 \%$ and ${ }^{*}$ for $10 \%$.

Finally, in order to estimate Equation (1), we employ the Fixed Effect estimator with both country and year fixed effects. Our choice is supported by standard diagnostic tests. In particular, we employ the F-test for detecting the presence of country and time fixed effects against Pooled-OLS. A Fixed Effect estimator is preferred to Random Effects on the basis of the Hausman test. See Table 4 for details.

\section{Conclusions}

The present work is aimed at empirically assessing the impact that price and real exchange rate volatility had on FDI inflows in a panel of Latin American countries, between 1990 and 2012. Using GARCH techniques for modeling volatility and the Fixed Effect estimator, our findings confirm the real option theory and, hence, the negative impact of exchange rate volatility on FDI inflows in Latin America. Moreover, it is shown that price volatility seems not to be relevant. Finally, human capital and trade openness are found to be key factors for attracting foreign capital. All these results are consistent with the established literature on developing countries.

From the policy perspective, our analysis suggests the importance of stabilization policies as well as the policy of government credibility in promoting trade openness and human capital formation.

To conclude, it is worth mentioning that our study can be extended in a number of ways, such as controlling for FDI types, industries' specific characteristics as well as the effects of recent crises. This is left for future research. 
Acknowledgments: We wish to thank two anonymous referees for useful and illuminating comments that have deeply improved the quality of our work. Further, special thanks go to David Snyder for proof-reading our manuscript, to Abay Mulatu and Christopher Tsoukis for useful comments at the initial stages of this project. Authors are also grateful to Gherardo Girardi and all the participants of the Conference on International Banking and Finance, London 2016, where the present work won the "Best Conference Paper Award". All the remaining errors are ours.

Author Contributions: Silvia Dal Bianco conceived the research questions as well as the paper outline and the analysis of the results obtained. Nguyen Cong To Loan reviewed the relevant literature, collected the data and contributed to data analysis and references' section.

Conflicts of Interest: The authors declare no conflict of interest.

\section{References}

1. Organisation for Economic Co-operation and Development (OECD). OECD Benchmark Definition of Foreign Direct Investment, 4th ed.; OECD Publishing: Paris, France, 2008.

2. Lipsey, R.E. Interpreting Developed Countries' Foreign Direct Investment. In Investing Today for the World of Tomorrow. Studies on the Investment Process in Europe; Deutsche Bundesbank, Ed.; Springer: Berlin, Germany, 2001; pp. 285-325.

3. Bruno, R.L.; Campos, N.F. Re-examining the Conditional Effect of Foreign Direct Investment. IZA Discussion Paper No. 7458 6/2013. 2013. Available online: http:/ /ftp.iza.org/dp7458.pdf (accessed on 15 December 2016).

4. Bloom, N. The Impact of Uncertainty Shocks. Econometrica 2009, 77, 623-685.

5. Arellano, C.; Bai, Y.; Kehoe, P.J. Financial Frictions and Fluctuations in Volatility. Federal Reserve Bank of Minneapolis Staff Report 466. Minneapolis, MN, USA, 2012. Available online: https:/ /www.minneapolisfed. org/research/sr/sr466.pdf (accessed on 15 December 2016).

6. Caggiano, G.; Castelnuovo, E.; Groshenny, N. Uncertainty Shocks and Unemployment Dynamics: An Analysis of Post-WWII US Recessions. J. Monet. Econ. 2014, 67, 78-92. [CrossRef]

7. Aastveit, K.A.; Natvik, G.J.; Sola, S. Economic Uncertainty and the Effectiveness of Monetary Policy; Norges Bank Working Paper Series; Norges Bank: Oslo, Norway, 2013, Volume 17. Available online: http://www.norges-bank.no/pages/95985/Norges_Bank_Working_Paper2013_17.pdf (accessed on 15 December 2016).

8. Mumtaz, H.; Surico, P. School of Economics and Finance, Policy Uncertainty and Aggregate Fluctuations; Working Paper; Queen Mary, University of London: London, UK, 2013.

9. Economic Commission for Latin America and the Caribbean (ECLAC). Foreign Direct Investment in Latin America and the Caribbean, 2015 (LC/G.2641-P); Santiago, Chile, 2015.

10. Dunning, J.H. The Eclectic Paradigm as an Envelope for Economic and Business Theories of MNE Activity. Int. Bus. Rev. 2000, 9, 163-190. [CrossRef]

11. Economic Commission for Latin America and the Caribbean (ECLAC). In Foreign Direct Investment in Latin America and the Caribbean, 2013 (LC/G.2613-P); Santiago, Chile, 2013.

12. Dal Bianco, S.; Amini, C.; Signorelli, M. The Impact of the Global Financial Crisis and the Role of External and Internal Factors in Emerging Economies. Emerg. Mark. Financ. Trade 2017, 53, 229-249. [CrossRef]

13. Abel, A. Optimal Investment under Uncertainty. Am. Econ. Rev. 1983, 73, 228-233.

14. Dixit, A.; Pindyck, R. Investment under Uncertainty; Princeton University Press: Princeton, NJ, USA, 1994.

15. Cushman, D. Real Exchange Rate Risk Expectations, and Exchange Rate Risk during the Floating Period. Rev. Econ. Stat. 1985, 67, 302-307.

16. Bernanke, B. Irreversibility, Uncertainty and Cyclical Investment. Q. J. Econ. 1983, 98, 85-106. [CrossRef]

17. Zeira, J. Cost Uncertainty and the Rate of Investment. J. Econ. Dyn. Control 1990, 14, 53-63. [CrossRef]

18. Dehn, J. Private Investment in Developing Countries: The Effects of Commodity Shocks and Uncertainty; Working Paper Series 2000-11; Center for the Study of African Economies, University of Oxford: Oxford, UK, 2000.

19. Udomkerdmongkol, M.; Morrissey, O.; Gorg, O. Exchange Rates and Outward Foreign Direct Investment: US FDI in Emerging Economies. Rev. Dev. Econ. 2009, 13, 754-764. [CrossRef]

20. Udoh, E.; Egwaikhide, F.O. Exchange Rate Volatility, Inflation Uncertainty and Foreign Direct Investment in Nigeria. Botsw. J. Econ. 2008, 5, 14-31. [CrossRef]

21. Del Bo, C. Foreign Direct Investment, Exchange Rate Volatility and Political Risk. In Proceedings of the European Trade Study Group (ETSG) Annual Conference, Vergata, Italy, 13-15 September 2009. 
22. Goldberg, L.S.; Kolstad, C.D. Foreign Direct Investment, Exchange Rate Variability, and Demand Uncertainty. Int. Econ. Rev. 1995, 36, 855-873. [CrossRef]

23. Chowdhury, A.; Wheeler, M. Does Real Exchange Rate Volatility Affect Foreign Direct Investment? Evidence from Four Developed Countries. Int. Trade J. 2008, 22, 218-245. [CrossRef]

24. Osinubi, T.S.; Amaghionyeodiwe, L.A. Foreign Direct Investment and Exchange Rate Volatility in Nigeria. Int. J. Appl. Econom. Quant. Stud. 2009, 6, 1-13.

25. Dhakal, D.; Nag, R.; Pradhan, G.; Upadhyaya, K.P. Exchange Rate Volatility and Foreign Direct Investment: Evidence From East Asian Countries. Int. Bus. Econ. Res. 2010, 9. [CrossRef]

26. Chaudhary, G.M.; Zulfiqar, S.; Bagram, M.M.M. Do Exchange Rate Volatility Effects Foreign Direct Investment? Evidence from Selected Asian Economies. J. Basic Appl. Sci. Res. 2012, 4, 3670-3681.

27. Lemi, A.; Asefa, S. Foreign Direct Investment and Uncertainty: Evidence from Africa. Afr. Financ. J. 2001, 5, 36-67.

28. Ullah, S.; Haider, S.Z.; Azim, P. Impact of Exchange Rate Volatility on FDI. Pak. Econ. So. Rev. 2012, 50, 121-138.

29. Gorg, H.; Wakelin, K. The Impact of Exchange Rate Volatility on US Direct Investment. Manch. Sch. 2002, 70, 380-397. [CrossRef]

30. Nyarko, P.A.; Nketiah-Amponsah, E.; Barnor, C. Effects of Exchange Rate Regimes on FDI Inflows in Ghana. Int. J. Econ. Financ. 2011, 3, 277. [CrossRef]

31. Santiso, J. La Emergencia de las Multilatinas. Rev. Cepal 2008, 95, 7-23.

32. Rugman, A.M.; Verbeke, A. Subsidiary-specific Advantages in Multinational Enterprises. Strateg. Manag. J. 2001, 22, 237-250. [CrossRef]

33. United Nations Conference on Trade and Development. World Investment Report Overview; United Nations Conference on Trade and Development (UNCTAD): New York, NY, USA, 2012 \& 2014.

34. Ajuwon, O.S. Macroeconomic Environment, Policy Uncertainty and Inflow of Foreign Direct Investment: Impact and Policy Implications for Nigeria. Mediterr. J. Soc. Sci. 2013, 4, 155-165.

35. Yousaf, S.; Shahzadi, I.; Kanwal, B.; Hassan, M. Impact of Exchange Rate Volatility on FDI in Pakistan. IOSR J. Bus. Manag. 2013, 12, 79-86. [CrossRef]

36. Mahmood, I.; Ehsanullah, M.; Ahmed, H. Exchange Rate Volatility \& Macroeconomic Variables in Pakistan. Bus. Manag. Dyn. 2011, 1, 11-22.

37. Hartman, R. The Effects of Price and Cost Uncertainty on Investment. J. Econ. Theory 1972, 5, $258-266$. [CrossRef]

38. Shleifer, A.; Vishny, R.W. The Limits of Arbitrage. J. Financ. 1997, 52, 35-55. [CrossRef]

39. Alfaro, L.; Chanda, A.; Kalemli-Ozcan, S.; Sayek, S. How Does Foreign Direct Investment Promote Economic Growth? Exploring the Effects of Financial Markets on Linkages. J. Dev. Econ. 2010, 91, 242-256. [CrossRef]

40. Alfaro, L.; Charlton, A. Growth and the Quality of Foreign Direct Investment: Is All FDI Equal? In The Industrial Policy Revolution I: The Role of Government beyond Ideology by Palgrave Macmillan; Springer: Berlin/Heidelberg, Germany, 2013.

41. Amal, M.; Tomio, B.T.; Raboch, H. Determinants of Foreign Direct Investment in Latin America. Rev. J. 2010, 4. [CrossRef]

42. Wang, Z.Q.; Swain, N.J. The Determinants of Foreign Direct Investment in Transforming Economies: Empirical Evidence from Hungary and China. Weltwirtschaftliches Arch. 1995, 131, 359-382. [CrossRef]

43. Ramirez, R.S.E. Integration and Foreign Investment in Latin America. In Handbook of Research on Economic Growth and Technological Change in Latin America; IGI Global: Hershey, PA, USA, 2014; pp. 105-124.

44. Abekah, J.Y. Overseas Private Investment Corporation and Its Effects on U.S. Direct Investment in Africa. J. Afr. Financ. Econ. Dev. 1998, 3, 43-64.

45. Baccini, L.; Urpelainen, J. International institutions and domestic politics: Can preferential trading agreements help leaders promote economic reform? J. Politics 2014, 76, 195-214. [CrossRef]

46. Buthe, T.; Milner, H.V. The Politics of Foreign Direct Investment into Developing Countries: Increasing FDI through International Trade Agreements? Am. J. Political Sci. 2008, 52, 741-762. [CrossRef]

47. Engel, R.F.; Granger, C.W.J. Co-Integration and Error Correction: Representation, Estimation, and Testing. Econometrica 1987, 55, 251-276. [CrossRef]

48. Granger, C.W.J.; Newbold, P. Spurious Regressions in Econometrics. J. Econom. 1974, 2, 111-120. [CrossRef]

49. Baltagi, B.H. Econometric Analysis of Panel Data, 2nd ed.; John Wiley \& Sons: New York, NY, USA, 2001. 
50. Taylor, M.P.; Sarno, L. The Behavior of Real Exchange Rates during the Post-Bretton Woods Period. J. Int. Econ. 1998, 46, 281-312. [CrossRef]

51. Maddala, G.S.; Wu, S. A Comparative Study of Unit Root Tests with Panel Data and a New Simple Test. Oxf. Bull. Econ. Stat. 1999, 61, 631-652. [CrossRef]

52. Choi, I. Unit Root Tests for Panel Data. J. Int. Money Financ. 2001, 20, 249-272. [CrossRef]

53. Engle, R. GARCH 101: The Use of ARCH/GARCH Models in Applied Econometrics. J. Econ. Perspect. 2001, 15, 157-168. [CrossRef]

54. Bollerslev, T. Generalized Autoregressive Conditional Heteroskedasticity. J. Econom. 1986, 31, $307-327$. [CrossRef] article distributed under the terms and conditions of the Creative Commons Attribution (CC BY) license (http:/ / creativecommons.org/licenses/by/4.0/). 